\title{
MICROBIAL RESPONSES TO DOSES OF COVER PLANT STRAW IN CERRADO PIAUIENSE OXISOL
}

\author{
RESPOSTAS MICROBIANAS A DOSES DE PALHADA DE PLANTAS DE \\ COBERTURA EM LATOSSOLO NO CERRADO PIAUIENSE
}

\section{Sarah Priscilla do Nascimento AMORIM ${ }^{1}$; Cácio Luiz BOECHAT ${ }^{2}$; Lizandra de Sousa Luz DUARTE ${ }^{3}$; Daniela Fernandes de OLIVEIRA ${ }^{4}$; João Carlos MEDEIROS ${ }^{5}$; Adriana Miranda de Santana ARAUCO ${ }^{2}$}

1. Mestre em Solos e Nutrição de Plantas, UFPI, Campus Prof ${ }^{a}$ Cinobelina Elvas, Bom Jesus, PI, Brasil; 2. Professor, Doutor, UFPI, Campus Prof ${ }^{a}$ Cinobelina Elvas, Bom Jesus, PI, Brasil. clboechat@hotmail.com; 3. Doutoranda em Ciência do Solo, UFRGS, Porto Alegre, RS, Brasil; 4. Mestranda em Ciência do Solo, UFRGS, Porto Alegre, RS, Brasil; Professor, Doutor, UFSB, Campus Jorge Amado, Itabuna, BA, Brasil.

\begin{abstract}
Carbon and nitrogen from the soil microbial biomass play a significant role in the rotation of $\mathrm{C}$ and $\mathrm{N}$, and promote nutrient cycling. Thus, the objective of this study was to evaluate changes in the soil microbial biomass with growing doses of cover plant straw species. The cover plants cultivated in the cerrado biome region were incorporated an Oxisol Ustox. The straw of each cover plant was incorporated at doses of $0 ; 10 ; 20$ and $30 \mathrm{Mg}$ ha- 1 . The soil basal respiration was determined by incubating, after 21 days. The microbial biomass carbon and nitrogen were determined by the method the microwave irradiation. The microbial biomass carbon and nitrogen contents in extracts were determined by the wet combustion method and Kjeldahl-N. The metabolic quotient was calculated as the ratio between soil basal respiration rate and microbial biomass $\mathrm{C}$, and the microbial quotient as the ratio between soil microbial biomass $\mathrm{C}$ and total carbon of soil. The soil microbial population measured by the attributes of quality responds to the addition of the of grass and legume straws incorporated to the soil; The treatments that cause the greatest stress to the microbial population, at 21 days, mediated by the metabolic quotient, are guandu-anão at a dose of $10 \mathrm{Mg} \mathrm{ha}^{-1}$; Guandu-anão and Guandu fava-larga at $20 \mathrm{Mg} \mathrm{ha}^{-1}$ and Brachiária at a dose of $30 \mathrm{Mg} \mathrm{ha}^{-1}$; The best result regarding microbial attributes of soil quality evaluated was observed with the incorporation of all doses of the straw of Crotalariaocroleuca.
\end{abstract}

KEYWORDS: Soil quality. Microbial attributes. Cover plants.

\section{INTRODUCTION}

Soil use is considered one of the main agents of global change due to its influence or the carbon $(\mathrm{C})$ and nitrogen $(\mathrm{N})$ cycles in the emission of greenhouse gases, mainly $\mathrm{CO}_{2}, \mathrm{CH}_{4}$ and $\mathrm{N}_{2} \mathrm{O}$. It is one off the factors that have the greatest direct impact on the chemical, physical and biological properties of agricultural soils (SMITH et al., 2016; SOUSA et al., 2017).

Soil conservation management systems represented by crop rotation, use of cover plants, direct sowing or minimum tillage have been widely practiced to mitigate the negative effects of conventional soil management practices, due to the soil and nutrient losses, exhaustion of organic matter, elevation of gas emissions in agricultural soils and losses of edaphic biodiversity (SOUSA et al., 2017; SILVA et al., 2018; MENDONÇA et al., 2018).

The use of conservationist cultivation practices and maintaining residues influence the soil microclimate, the distribution and decomposition of crop residues, mineralization and immobilization of nutrients, besides the edaphic fauna structure in soil (CHENG et al., 2017; SILVA et al., 2018). These changes can alter the microbial activity and biomass of the soil, besides the structure of the microbial community in agricultural soils (NASCIMENTO et al., 2016). Thus, agricultural soil management practices may markedly affect microbial activity, the rate of organic matter rotation and, finally carbon and nitrogen cycling in soil (LI et al., 2018).

Carbon $\left(\mathrm{C}_{\text {mic }}\right)$ and nitrogen $\left(\mathrm{N}_{\text {mic }}\right)$ from the soil microbial biomass play a significant role in the rotation of $\mathrm{C}$ and $\mathrm{N}$, and therefore promote nutrient cycling (BOECHAT et al., 2012). Despite being small, the soil microbial biomass reservoir is an important labile and living fraction of soil organic matter. Therefore, it is not only an agent to transform and cycle organic matter, it is also a drain and/or source of nutrients for the plants (ZHANG et al., 2017).

Moreover, the microbial biomass in soil responds rapidly to changes in management practices, and is considered a sensitive indicator of 
changes in soil stability after changes in use. The response of $\mathrm{C}_{\text {mic }}$ and $\mathrm{N}_{\text {mic }}$ to the changes in the management and soil cover systems has been studied, but the results vary considerably for each region (MUNIZ et al., 2018).

Thus, the objective of this study was to evaluate changes in the soil microbial biomass with growing doses of cover plant straw species.

\section{MATERIAL AND METHODS}

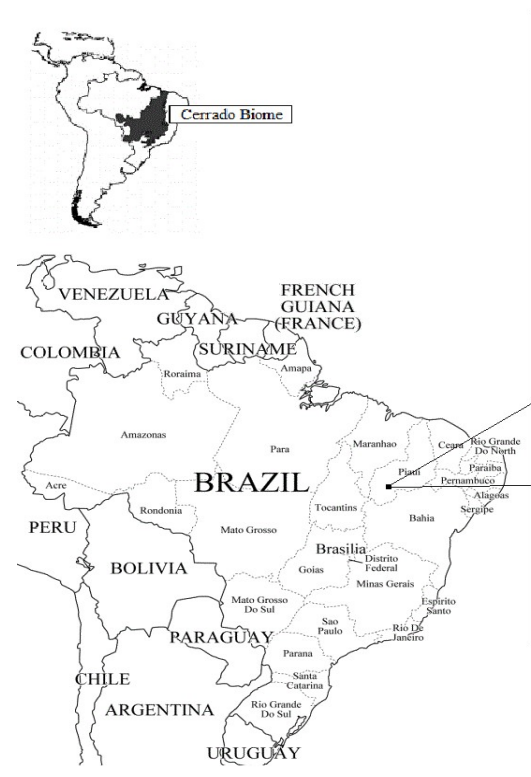

AMORIM, S. P. N. et al.

\section{Cover plant straws}

The millet BRS 1501 (Pennisetum glaucum) and brachiaria (Braquiária brizanta) grasses and the crotalaria-spectabilis (Crotalária spectabilis), crotalaria-ochroleuca (Crotalária ochroleuca), guadu-forrageiro anão IAPAR 43 - Aratã (Cajanus cajan), guadu-forrageiro Fava-Larga (Cajanus cajan) and mucuna-preta (Mucuna aterrima) legumes were cultivated in the field in $12 \mathrm{~m} \mathrm{x} 12.6$ $\mathrm{m}$ plots at the geographical coordinates $07^{\circ} 51^{\prime} 01^{\prime}$ ' $\mathrm{S}$ and $45^{\circ} 12^{\prime} 49^{\prime \prime} \mathrm{W}$ in the cerrado biome region (Figure 1).

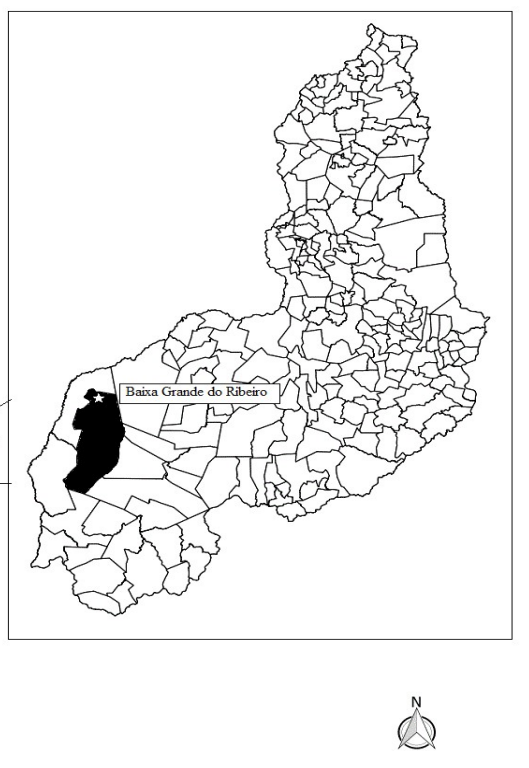

Figure 1. Location of the cover plants and soil sample collection in Piauí State, Northeast, Brazil.

At the time of sowing $173.4 ; 22.5 ; 0.45$ and $50 \mathrm{~kg} \mathrm{ha}^{-1}$ of boron (Borogran), sulfur (Sulfogran $90 \AA), \quad \mathrm{K}_{2} \mathrm{O} \quad(\mathrm{KCl})$ and $\mathrm{P}_{2} \mathrm{O}_{5}$ (Simple Super phosphate) respectively, were applied according to Souza and Lobato (2004). The cover species was sown directly passing a leveling harrow. The following amounts were used per hectare: $3.5 \mathrm{~kg}$ of brachiaria seed; $15 \mathrm{~kg}$ of C.espectabilis; $45 \mathrm{~kg}$ of guandu anão; $35 \mathrm{~kg}$ of millet; $60 \mathrm{~kg}$ of mucunapreta; $60 \mathrm{~kg}$ of guandu fava-larga and $10 \mathrm{~kg}$ of C. ochroleuca.

At 183 days after sowing plants were desiccated using two commercial formulations, based on potassium glyphosate and flumioxazin ${ }^{\circledR}$ herbicide at a dose of 2.0 and $0.1 \mathrm{~L} \mathrm{ha}^{-1}$, respectively. Samples of the dead cover plants were collected, placed in paper bags, identified, dried in an oven with forced air circulation at $65{ }^{\circ} \mathrm{C}$ for 48 hours and then fragmented into 1 to $3 \mathrm{~cm}$ fractions. Approximately, $1 \mathrm{~g}$ of each plant (dry mass) was weighed, digested with a nitro-perchloric acid solution in a warm open system and chemical characterization in the extract was performed in an atomic absorption spectrophotometer, and the nitrogen content by Kjeldahl distillation (TEDESCO et al., 1995). The results of the macro and micronutrient contents and the $\mathrm{C}: \mathrm{N}$ ratio are shown in Table 1.

\section{Soil sample characterization}

At the site where cover plants were cultivated, approximately $10 \mathrm{~kg}$ of soil were collected at the depth of $0-20 \mathrm{~cm}$. The soil was classified according to Brazilian Soil Classification System as Latossolo Amarelo eutrófico (SANTOS et al., 2013) or according to United States Department of Agriculture as Oxisol Ustox (SOIL SURVEY STAFF, 2014). The soil was stored in a dark environment with a controlled temperature of approximately $4{ }^{\circ} \mathrm{C} \pm 2$. Soil samples were air dried, sieved with a $2 \mathrm{~mm}$ mesh, homogenized, and then chemically and physically characterized according to a methodology described by Tedesco et al. (1995). The chemical and physical attributes of soil used in the tests are shown in Table 2. 
Table 1. Macro and micronutrient contents in the straw of single cover plant species.

\begin{tabular}{|c|c|c|c|c|c|c|c|c|c|c|}
\hline Cover plant straw & $\mathrm{Fe}$ & $\begin{array}{c}\mathrm{Mn} \\
\mathrm{mo} \mathrm{k}^{-1}\end{array}$ & $\mathrm{Zn}$ & $\mathrm{Mg}$ & $\mathrm{Ca}$ & $\begin{array}{l}\mathrm{P} \\
-1\end{array}$ & $\mathrm{~K}$ & $\mathrm{~N}_{0}$ & $\mathrm{C}$ & $\mathrm{C}: \mathrm{N}$ \\
\hline MI & 237.0 & 43.2 & 45.2 & 3.5 & 22.1 & 3.7 & 11.2 & 1.58 & 51.5 & 32.6 \\
\hline BR & 289.0 & 50.8 & 50.6 & 4.4 & 22.6 & 2.7 & 13.9 & 1.63 & 50.7 & 31.2 \\
\hline MP & 228.3 & 54.9 & 48.0 & 3.2 & 15.9 & 3.9 & 11.4 & 2.67 & 51.6 & 19.4 \\
\hline $\mathrm{CO}$ & 194.4 & 45.8 & 38.2 & 4.5 & 3.0 & 4.0 & 15.3 & 1.94 & 53.4 & 27.5 \\
\hline CS & 277.0 & 50.8 & 45.0 & 4.5 & 27.0 & 4.0 & 13.9 & 1.85 & 53.5 & 28.9 \\
\hline GF & 239.5 & 45.4 & 43.3 & 3.6 & 24.2 & 3.8 & 10.6 & 2.20 & 53.4 & 24.3 \\
\hline GA & 225.0 & 43.8 & 50.5 & 3.4 & 28.0 & 3.9 & 10.0 & 2.40 & 51.9 & 21.7 \\
\hline
\end{tabular}

MI - millet; BR - brachiaria; MP - mucuna-preta; CO - crotalaria-ochroleuca; CS - crotalaria-spectabilis; GF- guandu fava larga; GA guandu anão.

Table 2. Chemical and physical attributes of a soil sample used in the experimental tests

\begin{tabular}{|c|c|c|c|c|c|c|c|c|}
\hline \multirow{2}{*}{$\begin{array}{l}\mathrm{pH}_{\mathrm{H} 2 \mathrm{O}} \\
(1: 2.5) \\
5.9\end{array}$} & $\mathrm{H}+\mathrm{Al}$ & $\mathrm{Al}^{3+}$ & $\mathrm{Ca}^{2+}$ & $\mathrm{Mg}^{2+}$ & $\mathrm{Ca}+\mathrm{Mg}$ & $\begin{array}{l}\mathrm{P} \\
-\mathrm{m}\end{array}$ & ${ }_{1-3} \mathrm{~K}^{+}$ & $\begin{array}{l}\mathrm{OM} \\
\mathrm{g} \mathrm{kg}^{-1}\end{array}$ \\
\hline & 4.0 & 0.1 & 1.5 & 3.9 & 5.5 & 60.1 & 90.0 & 15.9 \\
\hline $\begin{array}{l}\mathrm{NH}_{4}^{+} \\
- \\
\end{array}$ & $\begin{array}{l}\mathrm{NO}_{3}^{-} \\
\mathrm{g}^{-1}\end{array}$ & SB & $\begin{array}{r}\mathrm{T} \\
\mathrm{n}^{-3} \\
\end{array}$ & $\mathrm{~V}$ & $\mathrm{~m}$ & Clay & $\begin{array}{c}\text { Silt } \\
\mathrm{g} \mathrm{kg}^{-1}\end{array}$ & Sandy \\
\hline 8.0 & 45.0 & 5.7 & 9.7 & 59.0 & 1.7 & 243.0 & 12.0 & 744.0 \\
\hline
\end{tabular}

The texture was determined by the densimeter method using $\mathrm{NaOH} 0.1 \mathrm{~mol} \mathrm{~L}^{-1}$; exchangeable $\mathrm{Ca}$ and $\mathrm{Mg}$ : extracted with $1 \mathrm{~mol} \mathrm{~L}{ }^{-1} \mathrm{KCl}$; Pand K: estimated by Mehlich-1; $\mathrm{H}+\mathrm{Al}$ : extracted with a solution of calcium acetate $0.5 \mathrm{~mol} \mathrm{~L}^{-1} \mathrm{pH} 7.0$; organic carbon was determined by the Walkley-Back combustion method (Tedesco et al., 1995). SB: sum of bases; m: Aluminum saturation; V: Bases saturation; T: cation exchange capacity at $\mathrm{pH} 7.0$.

\section{Experimental trials}

The experiment was conducted for 21 days at a controlled temperature of $28 \pm 2{ }^{\circ} \mathrm{C}$ and humidity near $70 \%$ of the field capacity using a BOD incubator in the absence of light. The moisture was checked by weighing every 7 days and adjusted with distilled water. The straw of each cover plant was incorporated at doses of 0 (soil without straw); 10; 20 and $30 \mathrm{Mg} \mathrm{ha}^{-1}$.

Treatments were distributed in a completely randomized experimental design in a factorial scheme of $8 \times 4+4$, with seven cover plant straws, Pennisetum glaucum (MI); B. brizanta (BR); C. spectabilis (CS); C. ochroleuca (CO); C. cajan (GA), C. cajan (GF) e M. aterrima (MP) incorporated into the soil and a treatment without incorporation of straw (control) and four doses of cover plant straws, $0 ; 10 ; 20$ and $30 \mathrm{Mg} \mathrm{ha}^{-1}$, with three replicates, plus four blank controls (without soil and straw), to eliminate the effect of atmospheric carbon dioxide $\left(\mathrm{CO}_{2}\right)$ contamination on the system in the assessment of soil basal respiration.

\section{Microbiological activity and biomass}

The soil basal respiration $\left(\mathrm{C}-\mathrm{CO}_{2}\right)$ was determined by incubating $100 \mathrm{~g}$ soil (dry weight) with the treatments in plastic bottles, placed on the surface of respirometric glass pots with tightly sealed screw caps. A second pot containing $30 \mathrm{ml}$ of $1 \mathrm{Mol} \mathrm{L}^{-1} \mathrm{NaOH}$ solution was added to capture $\mathrm{CO}_{2}$ and another containing $30 \mathrm{ml}$ of distilled water to keep the internal moisture constant.

After 21 days of incubation, accumulated C$\mathrm{CO}_{2}$ was withdrawn from the bottle with a solution of $\mathrm{NaOH}$ and added to $10 \mathrm{~mL}$ of $0.5 \mathrm{~mol} \mathrm{~L}^{-1} \mathrm{BaCl}_{2}$ and 3 drops of phenolphthalein indicator at $1 \%$. The amount of $\mathrm{CO}_{2}$ released from the soil was determined by titration of excess $\mathrm{NaOH}$ with 0.025 $\mathrm{Mol} \mathrm{L}{ }^{-1} \mathrm{HCl}$ solution. At each evaluation, the $1 \mathrm{Mol}$ $\mathrm{L}^{-1} \mathrm{NaOH}$ solution was replenished and the glass vessel resealed.

The microbial biomass carbon and nitrogen were determined by the method described by Vance, Brookes and Jenkinson (1987), using, instead of chloroform, the microwave irradiation technique proposed by Ferreira, Camargo and Vidor (1999) in order to kill the microorganisms and trigger the release of cellular components.

A solution of $\mathrm{K}_{2} \mathrm{SO}_{4} \quad 0.5 \quad \mathrm{Mol} \quad \mathrm{L}^{-1}$ (soil:extractant $=1: 4$ ) was added to the radiated and non- radiated soils followed by horizontal circular shaking at $220 \mathrm{rpm}$ for $30 \mathrm{~min}$. The extracts remained at rest for another 30 minutes and were filtered through Whatman ${ }^{\circledR} \mathrm{n}^{\circ} 42$ filter paper (diameter $7 \mathrm{~cm}$ ). The microbial biomass carbon $\left(\mathrm{C}_{\text {mic }}\right)$ and nitrogen $\left(\mathrm{N}_{\text {mic }}\right)$ contents in extracts were 
determined by the wet combustion method and Kjeldahl-N (TEDESCO et al., 1995).

The metabolic quotient $\left(\mathrm{qCO}_{2}\right)$ was calculated as the ratio between soil basal respiration rate and microbial biomass $\mathrm{C}$ and expressed as $\mathrm{mg}$ $\mathrm{CO}_{2} \mathrm{~g}^{-1} \mathrm{C}_{\text {min }} \mathrm{h}^{-1}$. The microbial quotient (qMIC) was calculated as the ratio between soil microbial biomass $\mathrm{C}$ and total carbon of soil expressed as $\%$.

\section{Statistical analysis}

Data were subjected to analysis of variance (ANOVA). The Scott-Knott's test at a significance level of $\mathrm{p}<0.05$ was used to compare mean values for each variable studied. The Sisvar program was used to analyze the data (FERREIRA, 2011).

\section{RESULTS AND DISCUSSION}

\section{Soil basal respiration}

The cover plant straws affect the microbial activity of soil 21 days after incorporation, measured by basal respiration $\left(\mathrm{C}-\mathrm{CO}_{2}\right)$ and nutrient cycling (Table 3 ).

Table 3. Basal respiration $\left(\mathrm{C}-\mathrm{CO}_{2}\right)$, carbon and nitrogen of the microbial biomass $\left(\mathrm{C}_{\text {mic }}\right.$ and $\left.\mathrm{N}_{\text {mic }}\right)$, metabolic quotient $\left(\mathrm{qCO}_{2}\right)$ and microbial quotient (qMIC) 21 days after the incorporation of 10, 20 and $30 \mathrm{Mg}$ $\mathrm{ha}^{-1}$ of cover plant straw to soil.

\begin{tabular}{|c|c|c|c|c|c|}
\hline \multirow[t]{2}{*}{ Treatment } & $\begin{array}{l}\mathrm{C}-\mathrm{CO}_{2} \\
\mathrm{mg} \mathrm{C}-\mathrm{CO}_{2} 100 \mathrm{~g}^{-1} \mathrm{~h}^{-1}\end{array}$ & \multicolumn{2}{|c|}{$-\operatorname{mg~} 100 \mathrm{~g}^{-1}-$} & $\begin{array}{l}q \mathrm{CO}_{2} \\
\mathrm{mg} \mathrm{C} \mathrm{CO}_{2} \mathrm{~g}^{-1} \mathrm{C}-\mathrm{BMS} \mathrm{h}\end{array}$ & $\begin{array}{l}q \mathrm{MIC} \\
\%\end{array}$ \\
\hline & $10 \mathrm{Mg} \mathrm{ha}^{-1}$ & & & & \\
\hline MI & $84.57 \mathrm{ab}$ & $32.72 \mathrm{c}$ & $7.34 \mathrm{a}$ & $2.84 \mathrm{~b}$ & $0.39 \mathrm{a}$ \\
\hline $\mathrm{BR}$ & $108.28 \mathrm{a}$ & $167.27 \mathrm{a}$ & $6.48 \mathrm{a}$ & $0.68 \mathrm{~b}$ & $1.52 \mathrm{a}$ \\
\hline MP & $83.78 \mathrm{ab}$ & $105.45 \mathrm{ab}$ & $4.75 \mathrm{a}$ & $0.81 \mathrm{~b}$ & $1.13 \mathrm{a}$ \\
\hline $\mathrm{CS}$ & $101.17 \mathrm{a}$ & $160.00 \mathrm{a}$ & $3.02 \mathrm{a}$ & $0.92 \mathrm{~b}$ & $1.34 \mathrm{a}$ \\
\hline $\mathrm{CO}$ & $101.17 \mathrm{a}$ & $134.54 \mathrm{a}$ & $3.88 \mathrm{a}$ & $0.70 \mathrm{~b}$ & $1.89 \mathrm{a}$ \\
\hline $\mathrm{GF}$ & $86.94 \mathrm{ab}$ & $50.90 \mathrm{bc}$ & $12.53 \mathrm{a}$ & $1.82 \mathrm{~b}$ & $1.25 \mathrm{a}$ \\
\hline GA & $103.14 \mathrm{a}$ & $18.18 \mathrm{c}$ & $6.61 \mathrm{a}$ & $6.19 \mathrm{a}$ & $0.22 \mathrm{a}$ \\
\hline \multirow[t]{2}{*}{ Test } & $34.38 \mathrm{~b}$ & $36.36 \mathrm{bc}$ & $4.75 \mathrm{a}$ & $0.98 \mathrm{~b}$ & $0.29 \mathrm{a}$ \\
\hline & $20 \mathrm{Mg} \mathrm{ha}^{-1}$ & & & & \\
\hline MI & $133.57 \mathrm{a}$ & $58.18 \mathrm{~b}$ & $15.12 \mathrm{ab}$ & 2.97 abcd & $0.58 \mathrm{bc}$ \\
\hline $\mathrm{BR}$ & $135.55 \mathrm{a}$ & $36.36 \mathrm{~b}$ & $3.02 \mathrm{c}$ & $3.88 \mathrm{abc}$ & $0.30 \mathrm{c}$ \\
\hline MP & $129.62 \mathrm{a}$ & $174.54 \mathrm{a}$ & $3.88 \mathrm{c}$ & $0.76 \mathrm{c}$ & $2.28 \mathrm{ab}$ \\
\hline $\mathrm{CS}$ & $148.20 \mathrm{a}$ & $94.54 \mathrm{~b}$ & $19.44 \mathrm{a}$ & $1.63 \mathrm{bcd}$ & $1.00 \mathrm{bc}$ \\
\hline $\mathrm{CO}$ & $145.43 \mathrm{a}$ & $221.81 \mathrm{a}$ & $4.75 \mathrm{c}$ & $0.67 \mathrm{c}$ & $3.18 \mathrm{a}$ \\
\hline GF & $153.33 \mathrm{a}$ & $32.72 b$ & $10.80 \mathrm{abc}$ & $5.50 \mathrm{a}$ & $0.46 \mathrm{bc}$ \\
\hline GA & $139.11 \mathrm{a}$ & $36.36 \mathrm{~b}$ & $9.07 \mathrm{bc}$ & $4.42 \mathrm{ab}$ & $0.47 \mathrm{bc}$ \\
\hline \multirow[t]{2}{*}{ Test } & $34.38 \mathrm{~b}$ & $36.36 \mathrm{~b}$ & $4.75 \mathrm{c}$ & $0.98 \mathrm{bc}$ & $0.29 \mathrm{c}$ \\
\hline & $30 \mathrm{Mg} \mathrm{ha}^{-1}$ & & & & \\
\hline MI & $164.01 \mathrm{a}$ & $214.54 \mathrm{a}$ & $11.66 \mathrm{bc}$ & $0.76 \mathrm{~b}$ & $2.38 \mathrm{ab}$ \\
\hline $\mathrm{BR}$ & $195.22 \mathrm{a}$ & $29.09 \mathrm{~d}$ & $19.44 \mathrm{ab}$ & $7.03 \mathrm{a}$ & $0.28 \mathrm{c}$ \\
\hline MP & $166.37 \mathrm{a}$ & $138.18 \mathrm{~b}$ & $6.48 \mathrm{c}$ & $1.22 \mathrm{~b}$ & $1.87 \mathrm{abc}$ \\
\hline $\mathrm{CS}$ & $196.41 \mathrm{a}$ & $116.36 \mathrm{bc}$ & $3.88 \mathrm{c}$ & $1.71 \mathrm{~b}$ & $1.32 \mathrm{bc}$ \\
\hline $\mathrm{CO}$ & $177.44 \mathrm{a}$ & $240.0 \mathrm{a}$ & $8.20 \mathrm{c}$ & $0.76 \mathrm{~b}$ & $3.69 \mathrm{a}$ \\
\hline GF & $165.19 \mathrm{a}$ & $50.90 \mathrm{~cd}$ & $21.17 \mathrm{ab}$ & $3.50 \mathrm{~b}$ & $1.20 \mathrm{bc}$ \\
\hline GA & $184.95 \mathrm{a}$ & $98.18 \mathrm{bcd}$ & $27.22 \mathrm{a}$ & $2.06 \mathrm{~b}$ & $1.19 \mathrm{bc}$ \\
\hline Test & $34.38 \mathrm{~b}$ & $36.36 \mathrm{~d}$ & $4.75 \mathrm{c}$ & $0.98 \mathrm{~b}$ & $0.29 \mathrm{c}$ \\
\hline C.V. $(\%)$ & 16.2 & 28.74 & 43.15 & 52.06 & 61.61 \\
\hline
\end{tabular}

MI - millet; BR - brachiaria; MP - mucuna-preta; CO - crotalaria-ochroleuca; CS - crotalaria-spectabilis; GF- guandu fava larga; GA guandu anão. C.V.: coefficient of variation.

Soil basal respiration (SBR) in treatments with plant cover straw at all doses evaluated, was greater than the control (soil without straw). Besides, all the treatments presented linearly growing $\mathrm{C}-\mathrm{CO}_{2}$ values with the increase of the doses applied (Figure 2), indicating the elevation of microorganism activity by the increased release of carbon dioxide $\left(\mathrm{C}-\mathrm{CO}_{2}\right)$ from the soil (Table 3$)$. 


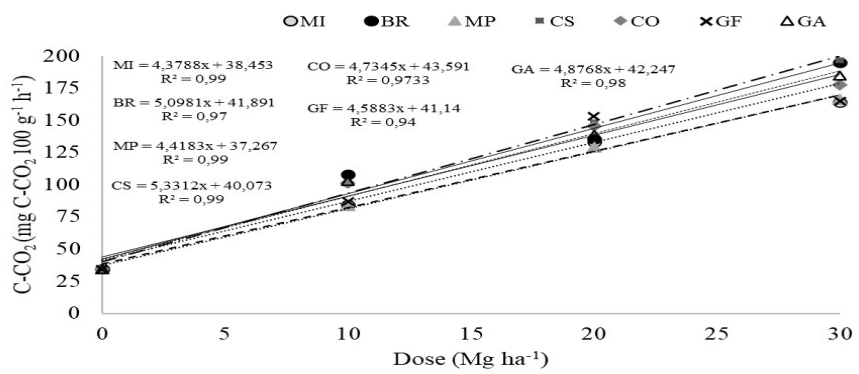

Figure 2. Soil basal respiration $\left(\mathrm{C}-\mathrm{CO}_{2}\right) 21$ after the incorporation of doses of vegetal straw from cover plants. MI - millet; BR - brachiaria; MP - mucuna-preta; CO - crotalaria-ochroleuca; CS - crotalariaspectabilis; GF- guandu fava larga; GA - guandu anão.

This increased activity occurs because SBR is a microbial attribute related to soil fertility, since it plays an important role in the degradation of organic matter and nutrient cycling (BOECHAT et al., 2012; MOURA et al., 2015). The degradation and activity processes of the microbial population usually result from the quality of the organic matter, for instance the $\mathrm{C}, \mathrm{P}$ and $\mathrm{N}$ content of the residues generally stimulate the development of the microbial community in the soil (BOECHAT et al., 2012; LI et al., 2016). Besides, this attribute is considered a sensitive indicator of soil quality (ROMERO-FREIRE et al., 2016).

\section{Microbial biomass}

Microbial biomass carbon $\left(\mathrm{C}_{\text {mic }}\right)$ is a major component of soil quality, since it responds more promptly to environmental changes than any other agronomic and yield parameter because it is related to processes such as the decomposition of organic compounds, nutrient cycling, degradation of xenobiotics and organic pollutants (KASCHUK; ALBERTON; HUNGRIA, 2009).
The incorporation of straw to treatments $\mathrm{BR}, \mathrm{MP}, \mathrm{CS}$ and $\mathrm{CO}$ at a dose of $10 \mathrm{Mg} \mathrm{ha}^{-1}$, increased the microbial population of the soil with values of $167.27 ; 83.78 ; 160.0$ and $134.54 \mathrm{mg} 100 \mathrm{~g}^{-}$ 1 of soil, respectively, compared to the other treatments. At a dose of $20 \mathrm{Mg} \mathrm{ha}^{-1}$, increased microbial population measured by the microbial carbon content was observed in treatments $\mathrm{CO}$ and MP (221.81 and $174.54 \mathrm{mg} 100 \mathrm{~g}^{-1}$ of soil, respectively) and at the dose of $30 \mathrm{Mg} \mathrm{ha}^{-1}$, the treatments incorporating the straws of $\mathrm{MI}$ and $\mathrm{CO}$ were outstanding $\left(214,54\right.$ and $240,0 \mathrm{mg} 100 \mathrm{~g}^{-1}$ of soil, respectively). The lowest values of $\mathrm{C}_{\text {mic }}$ were observed in the control and in the BR treatment (36.36 and $29.09 \mathrm{mg} 100 \mathrm{~g}^{-1}$ of soil, respectively) (Table 3).

Among the straws from cover plants studied, the crotalaria-ochroleuca was outstanding in variable $\mathrm{C}_{\text {mic }}$ at all doses evaluated (Figure 3), indicating energy cycling and nutrient transfer in the soil system, which will benefit the subsequent crop. Although these doses will be difficult to achieve in a single crop, they may be achieved through cycles of the non-tillage system.

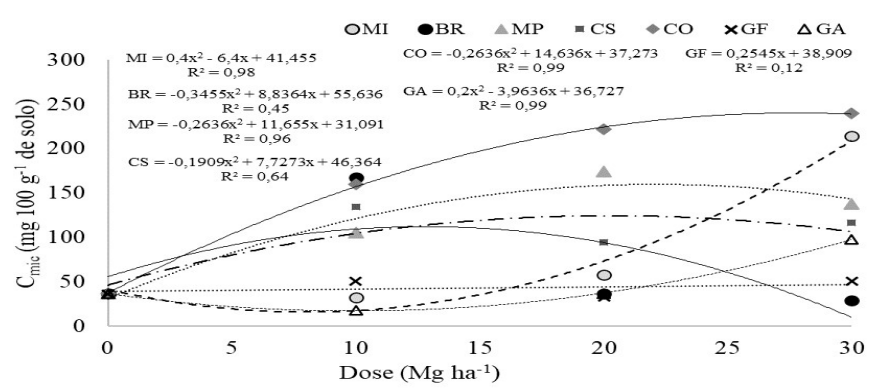

Figure 3. Microbial carbon of the soil 21 days after incorporating doses of straw from cover plants. MI - millet; BR - brachiaria; MP - mucuna-preta; CO - crotalaria-ochroleuca; CS - crotalaria-spectabilis; GFguandu fava larga; GA - guandu anão.

There was no difference in the nitrogen content of the microbial biomass $\left(\mathrm{N}_{\text {mic }}\right)$ between the treatments at a dose of $10 \mathrm{Mg} \mathrm{ha}^{-1}$. At a dose of 20 $\mathrm{Mg} \mathrm{ha}{ }^{-1}$ higher values were observed (19.44; 15.12 and $10.80 \mathrm{mg} 100 \mathrm{~g}^{-1}$ of soil) in treatments with straw of CS, MI and GF, respectively. For the same dosage, the treatments $\mathrm{CO}, \mathrm{BR}, \mathrm{MP}$ and control presented the lowest values. At a dose of $30 \mathrm{Mg} \mathrm{ha}^{-1}$ 
the highest values of $\mathrm{N}_{\text {mic }}$ were observed in the $\mathrm{BR}$, GF and GA treatments with values of $19.44 ; 21.17$ and $27.22 \mathrm{mg} 100 \mathrm{~g}^{-1}$ of soil and the lowest were observed in the MP, CS and control (Table 3).

The microbial biomass of the soil may be a source or drain of available nutrients, mediating a major role in transforming nutrients in the terrestrial ecosystems (SINGH; REGHBANSHI; SINGH, 1989). The nitrogen content in the microbial biomass varied between the treatments at the doses of 20 and $30 \mathrm{Mg} \mathrm{ha}^{-1}$, indicating that the cover plant straws, even presenting macro and micronutrient contents and a $\mathrm{C} / \mathrm{N}$ ratio that were very close (Tables 1 and 3), are not sufficient to predict the behavior of the soil microbial population
According to Gama-Rodrigues (1999), in environments with a high concentration of $\mathrm{N}$, the quantity of $\mathrm{N}$ immobilized by the soil microbial biomass would be smaller, since this element would be sufficient to cover the metabolic activity of the microorganisms and the decomposition process of organic matter. Possibly this is the explanation for the values observed in the treatments with straw, that presented high $\mathrm{C}_{\text {mic }}$ values and low $\mathrm{N}_{\text {mic }}$ values, except for the soil without straw (control).

The values of $\mathrm{N}_{\text {mic }}$ indicate that there was a difference between the doses used in each plant straw (Figure 4).

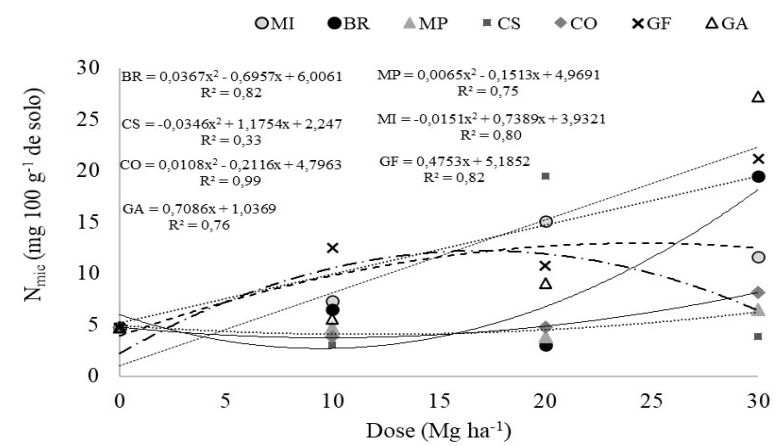

Figure 4. Microbial nitrogen in soil 21 days after incorporating doses of straw from cover plants. MI - millet; BR - brachiaria; MP - mucuna-preta; CO - crotalária-ochroleuca; CS - crotalária-spectabilis; GFguandu fava larga; GA - guandu anão.

For the treatments with CS and MI, the maximum value was obtained close to the dose of $20 \mathrm{Mg} \mathrm{ha}^{-1}$, differing from the other treatments that obtained the highest values at the dose of $30 \mathrm{Mg} \mathrm{ha}^{-1}$ (Table 3 ). The residue quality influenced $\mathrm{N}_{\text {mic }}$, and the highest values were observed in the GA and GF legumes. Mineralization and immobilization of the organic matter in the soil present a complex dynamic. When an organic residue is added to the soil under conditions of equilibrium, microbial activity increases because of the increased oxidizable C.

\section{Metabolic and microbial quotients}

The metabolic quotient $\left(\mathrm{qCO}_{2}\right)$ of soil is a sensitive indicator of biological activity and substrate quality (BOECHAT et al., 2012). Considering that soil respiration per unit of microbial biomass is diminished in more stable systems (INSAM; DOMSCH, 1988), the treatments with higher values for these attributes were considered less stable, and the highest value observed in the GA treatment was at a dose of 10 $\mathrm{Mg} \mathrm{ha}^{-1}$ compared to the other treatments $(6.19 \mathrm{mg}$ $\left.\mathrm{C}-\mathrm{CO}_{2} \mathrm{~g}^{-1} \mathrm{C}_{\text {mic }} \mathrm{h}^{-1}\right)$. At the dose of $20 \mathrm{Mg} \mathrm{ha}^{-1}$ the highest values were observed in the GF and GA treatments $\left(5.50\right.$ and $4.42 \mathrm{mg} \mathrm{C}-\mathrm{CO}_{2} \mathrm{~g}^{-1} \mathrm{C}_{\text {mic }} \mathrm{h}^{-1}$, respectively). The highest value $\left(7.03 \mathrm{mg} \mathrm{C}-\mathrm{CO}_{2} \mathrm{~g}^{-}\right.$ ${ }^{1} \mathrm{C}_{\text {mic }} \mathrm{h}^{-1}$ ) was observed at the dose of $30 \mathrm{Mg} \mathrm{ha}^{-1}$ was observed after the incorporation of the brachiaria (BR) straw (Table 3).

A high $\mathrm{qCO}_{2}$ may occur because of less availability of nutrients for the soil microbiota (GAMA-RODRIGUES; GAMA-RODRIGUES; BARROS, 1997). The quantity of straw incorporated to the soil influences the efficiency of the microorganisms to use the substrate and incorporate $\mathrm{C}$ to their biomass. As the microbial population becomes more efficient, less $\mathrm{C}$ will be lost as $\mathrm{CO}_{2}$ and more $\mathrm{C}$ will be incorporated to the microbial tissue. This is related to the $\mathrm{C} / \mathrm{N}$ ratio of the materials (KUZYAKOV, 2010).

When BR straw was incorporated, the value

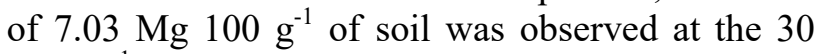
$\mathrm{Mg} \mathrm{ha}{ }^{-1}$ dose, and it was superior for this variable (Figure 5). These higher values indicate a possible stress on the soil microbiota, since the repairs of damages caused by environmental disturbance require a diversion of energy from growth and reproduction to cell maintenance. In this way, a 
proportion of carbon from the biomass will be lost as $\mathrm{CO}_{2}$. Only the treatments using $\mathrm{CS}$ doses presented linear growth among the doses applied, ranging from 0.92 and $1.71 \mathrm{Mg} 100 \mathrm{~g}^{-1}$ of soil. These results are inferior to almost all treatments used in this trial, and superior only to the treatment using MP and CO.
AMORIM, S. P. N. et al.

When they worked with the production of phytomass from nine different cover species in cerrado soil, Carneiro et al. (2008), observed lower values of $\mathrm{CO}_{2}$ in the areas under Crotalaria juncea oats and guandu residues, showing the positive effect of residues from these covers on the soil microbial population.

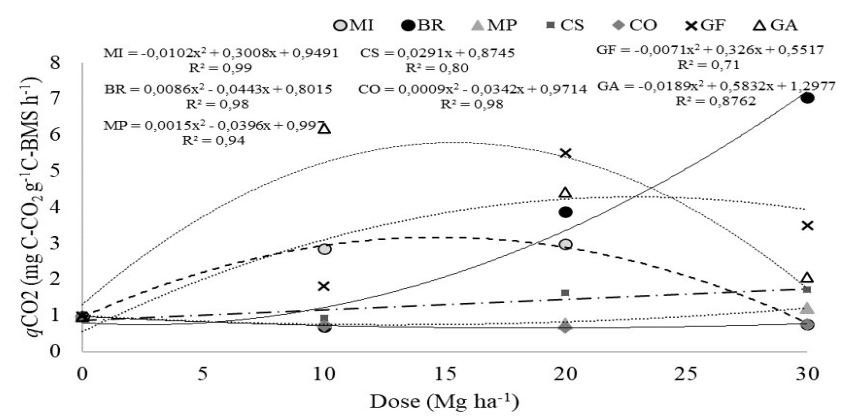

Figure 5. Metabolic quotient of soil $\left(\mathrm{qCO}_{2}\right) 21$ days after the incorporation of the vegetal straw. MI - millet; BR - brachiaria; MP - mucuna-preta; CO - crotalaria-ochroleuca; CS - crotalaria-spectabilis; GFguandu fava larga; GA - guandu anão.

The microbial quotient (qMIC) at a dose of $10 \mathrm{Mg} \mathrm{ha}^{-1}$ was not different among treatments. For the $20 \mathrm{Mg} \mathrm{ha}^{-1}$ dose, treatments with CO and MP presented the highest results (3.10 and $2.28 \%)$ and the lowest values were observed in the control and in the BR straw $(0.29$ and $0.30 \%)$. At the $30 \mathrm{Mg}$ ha ${ }^{1}$ dose, the treatments that used the $\mathrm{CO}$, MI and MP straws presented the highest values $(3.69 ; 2.38$ and $1.87 \%$, respectively) (Table 3 ).

The values found suggest that organic $\mathrm{C}$ is available to the soil microbiota, since this relation is an indicator of availability of organic matter to the microorganisms, and a qMIC above 1 , indicates active organic matter subject to transformations (SAMPAIO; ARAÚJO; SANTOS, 2008), evidencing the beneficial influence of the straw on soil microbial activity, compared to the control that does not incorporate straw at the dose studied (Table $3)$.

For qMIC the CO treatment with straw from the crotalaria-ochroleuca obtained the highest means, and the maximum peak was observed at the dose of $30 \mathrm{Mg} \mathrm{ha}^{-1}$, different from the BR and CS treatments where the maximum value occurred close to the $20 \mathrm{Mg} \mathrm{ha}^{-1}$ dose (Figure 6).

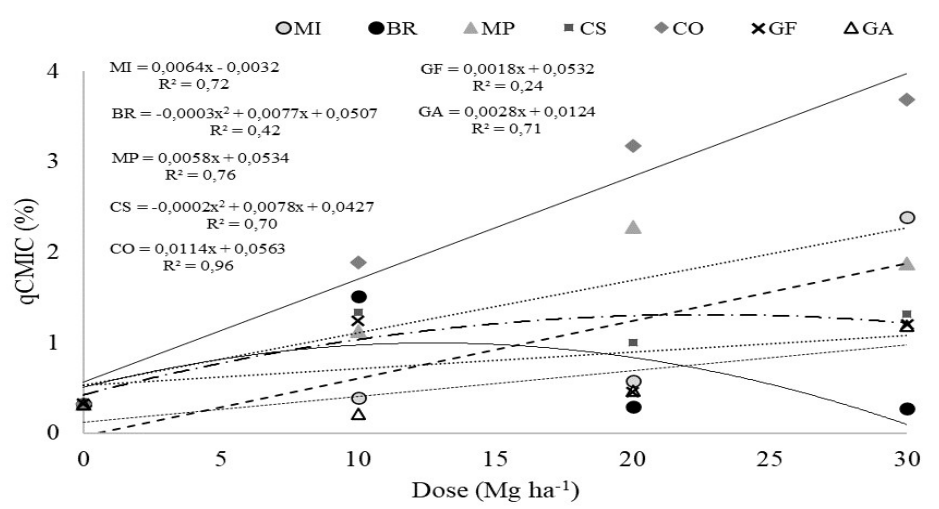

Figure 6. Soil microbial quotient (qMIC) 21 after the incorporation of cover plant straw. MI-millet; BR brachiaria; MP - mucuna-preta; CO - crotalaria-ochroleuca; CS - crotalaria-spectabilis; GF- guandu fava larga; GA - guandu anão. 
The values of qMIC found express the occurrence of an accumulation or loss of $\mathrm{C}$ from the soil, values lower than 1 suggest to us that some factor that limits soil microbial activity is present (JAKELAITIS et al., 2008). Values below the microbial quotient suggest that organic $\mathrm{C}$ is not available to the soil microbiota, since the $\mathrm{C}_{\text {mic }}$ :COT ratio is an indicator of the availability of organic matter to the microorganisms, and a high microbial quotient indicates very active organic matter subject to transformations (SAMPAIO; ARAÚJO; SANTOS, 2008).

\section{CONCLUSIONS}

At 21 days the soil microbial population measured by the attributes of quality responds to the addition of the amount of grass and legume straws incorporated to the soil.
The treatments that cause the greatest stress to the microbial population, at 21 days, mediated by the metabolic quotient, are guandu-anão at a dose of $10 \mathrm{Mg} \mathrm{ha}^{-1 ;}$ Guandu-anão and Guandu fava-larga at $20 \mathrm{Mg} \mathrm{ha}^{-1}$ and Brachiária at a dose of $30 \mathrm{Mg} \mathrm{ha}^{-1}$; Basal respiration responds linearly and increasingly to the greater quantity of straw incorporated to the soil and the other attributes respond randomly to this stimulus and to the type of cover plant.

The best result regarding microbial attributes of soil quality evaluated during 21 days was observed with the incorporation of all doses of the straw of Crotalaria-ocroleuca.

\section{ACKNOWLEDGEMENTS}

The authors thank the CAPES for a Master's degree scholarship for the first author, $\mathrm{CNPq}$ for financial support and the company Piraí Sementes for kindly donating the seeds.

RESUMO: O carbono e nitrogênio da biomassa microbiana do solo desempenham um papel significativo na rotação de $\mathrm{C}$ e N, promovendo o ciclo de nutrientes. Assim, o objetivo deste trabalho foi avaliar mudanças na biomassa microbiana do solo com doses crescentes de palha de cobertura. As plantas de cobertura cultivadas no bioma cerrado foram incorporadas a um Latossolo Amarelo Eutrófico. A palha de cada planta de cobertura foi incorporada em doses de $0 ; 10 ; 20$ e $30 \mathrm{Mg} \mathrm{ha}^{-1}$. A respiração basal do solo foi determinada por incubação, após 21 dias. O carbono e nitrogênio da biomassa microbiana foram determinados pelo método da irradiação de micro-ondas, os seus teores de carbono e nitrogênio da biomassa microbiana nos extratos foram determinados pelo método de combustão úmida e Kjeldahl-N. O quociente metabólico foi calculado como a razão entre a taxa de respiração basal do solo e a biomassa microbiana, e o quociente microbiano a razão entre a biomassa microbiana do solo e o carbono total do solo. A população microbiana do solo medida pelos atributos de qualidade responde à adição de palhas de gramíneas e leguminosas incorporadas ao solo; Os tratamentos que causam maior estresse à população microbiana, aos 21 dias, mediados pelo quociente metabólico, são o guandu-anão na dose de $10 \mathrm{Mg} \mathrm{ha}^{-1}$; Guandu-anão e Guandu fava-larga a $20 \mathrm{Mg} \mathrm{ha}^{-1} \mathrm{e}$ Brachiária na dose de $30 \mathrm{Mg} \mathrm{ha}^{-1}$; $\mathrm{O}$ melhor resultado em relação aos atributos microbianos de qualidade do solo avaliados foi observado com a incorporação de palha de Crotalaria-ocroleuca.

PALAVRAS-CHAVE: Qualidade do solo. Atributos microbianos. Plantas de cobertura.

\section{REFERENCES}

BOECHAT, C. L.; SANTOS, J. A. G.; ACCIOLY, A. M. A.; BOMFIM, M. R.; SANTOS, A. C. Industrial and urban organic wastes increase soil microbial activity and biomass. Revista Brasileira de Ciência do Solo, v. 36, p. 1629-1636, 2012. https://doi.org/10.1590/S0100-06832012000500027

CARNEIRO, M. A. C.; COEDEIRO M. A. S.; ASSIS, P. C. R.; MORAES, E. S.; PEREIRA, H. S.; PAULINO, H. B.; SOUZA, E. D.; Produção de fitomassa de diferentes espécies de cobertura e suas alterações na atividade microbiana de solo de cerrado. Bragantia, v. 67, n. 2, p. 455-462, 2008. https://doi.org/10.1590/S000687052008000200021

CHENG, Y.; WANG, J.; WANG, J.; CHANG, S. X.; WANG, S. The quality and quantity of exogenous organic carbon input control microbial $\mathrm{NO}_{3}{ }^{-}$immobilization: a meta-analysis. Soil Biology and Biochemistry, v. 115 , p. 357-363, 2017. https://doi.org/10.1016/j.soilbio.2017.09.006 
FERREIRA, A. S.; CAMARGO, F. A. O.; VIDOR, C. Utilização de microondas na avaliação da biomassa microbiana do solo. Revista Brasileira de Ciência do Solo, v. 23, p. 991-996, 1999.

https://doi.org/10.1590/S0100-06831999000400026

FERREIRA, D. F. Sisvar: a computer statistical analysis system. Ciência e Agrotecnologia, v. 35, p. 10391042, 2011. https://doi.org/10.1590/S1413-70542011000600001

GAMA-RODRIGUES, E. F.; GAMA-RODRIGUES, A. C.; BARROS, N. F. Biomassa microbiana de carbono e de nitrogênio de solos sob diferentes coberturas florestais. Revista Brasileira de Ciência do Solo, v. 21 , p. 361-365, 1997. https://doi.org/10.1590/S0100-06831997000300002

GAMA-RODRIGUES, E. F. Biomassa microbiana e ciclagem de nutrientes. In: SANTOS, G. A. \& CAMARGO, F. A. O., (Ed.). Fundamentos de matéria orgânica do solo. Ecossistemas tropicais e subtropicais. Gêneses: Porto Alegre, 1999. p. 227-243.

INSAM, H.; DOMSCH, K. H. Relationship between soil organic carbon and microbial biomass on chronosequences of reclamation sites. Microbial Ecology, v. 47, p. 177-188, 1988.

https://doi.org/10.1007/BF02011711

JAKELAITIS, A.; SILVA, A. A.; SANTOS, J. B.; VIVIAN, R. Qualidade da camada superficial de solo sob mata, pastagens e áreas cultivadas. Pesquisa Agropecuária Tropical, v. 38, p. 118-127, 2008.

KASCHUK, G.; ALBERTON, O.; HUNGRIA, M. Three decades of soil microbial biomass studies in Brazilian ecosystems: Lessons learned about soil quality and indications for improving sustainability. Soil Biology and Biochemistry, v. 42, p. 1-13, 2009. https://doi.org/10.1016/j.soilbio.2009.08.020

KUZYAKOV, Y. Priming effects: Interactions between living and dead organic matter. Soil Biology and Biochemistry, v. 42, p. 1363-1371, 2010. https://doi.org/10.1016/j.soilbio.2010.04.003

LI, Y.; CHANG, S. X.; TIAN, L.; ZHANG, Q. Conservation agriculture practices increase soil microbial biomass carbon and nitrogen in agricultural soils: A global meta-analysis. Soil Biology and Biochemistry, v. 121, p. 50-58, 2018. https://doi.org/10.1016/j.soilbio.2018.02.024

LI, Q.; SONG, X.; GU, H.; GAO, F. Nitrogen deposition and management practices increase soil microbial biomass carbon but decrease diversity in Moso bamboo plantations. Scientific Reports, v. 6, Article number: 28235, 2016. https://doi.org/10.1038/srep28235

MENDONÇA, P. G.; TEIXEIRA, D. B.; MOITINHO, M. R.; SILVA JUNIOR, J. F.; OLIVEIRA, I. R.; MARTINS FILHO, M. V.; MARQUES JUNIOR, J.; PEREIRA, G. T. Temporal and spatial uncertainty of erosion soil loss from an argisol under sugarcane management scenarios. Revista Brasileira de Ciência do Solo, v. 42: e0170182, p. 1-15, 2018. https://doi.org/10.1590/18069657rbcs20170182

MOURA, J. A.; GONZAGA, M. I. S.; ANJOS, J. L.; RODRIGUES, A. C. P.; LEÃO, T. D. S.; SANTOS, L. C. O. Respiração basal e relação de estratificação em solo cultivado com citros e tratado com resíduos orgânicos no estado de Sergipe. Semina: Ciências Agrárias, v. 36, p. 731-746, 2015. https://doi.org/10.5433/1679$0359.2015 \mathrm{v} 36 \mathrm{n} 2 \mathrm{p} 731$

MUNIZ, A. W.; NUNES, R. H. S.; SILVA, T. A. C.; SÁ, E. L. S.; MAJOLO, C.; FIUZA, A. B.; CAVALLAZZI, J. R. P. No-tillage effect on carbon and microbiological attributes in corn grown in ManausAM, Brazil. African Journal of Agricultural Research, v. 13, p. 77-81, 2018. https://doi.org/10.5897/AJAR2017.12805 
NASCIMENTO, P. G. M. L.; CRUZ, B. L. S.; DANTAS, A. M. M.; FREITAS, F. C. L.; AMBRÓSIO, M. M. Q.; SALES JÚNIOR, R. Microbial communities in soil cultivated with muskmelon under different management systems. Revista Brasileira de Ciência do Solo, v. 40, p. 1-15, 2016.

https://doi.org/10.1590/18069657rbcs20160130

ROMERO-FREIRE, A.; ARAGÓN, M. S.; GARZÓN, F. J. M.; PEINADO F. J. M. Is soil basal respiration a good indicator of soil pollution? Geoderma, v. 263, p. 132-139, 2016.

https://doi.org/10.1016/j.geoderma.2015.09.006

SAMPAIO, D. B.; ARAÚJO, A. S. F.; SANTOS, V. B. Avaliação de indicadores biológicos de qualidade do solo sob sistemas de cultivo convencional e orgânico de frutas. Ciência e Agrotecnologia, v. 32, p. 353-359, 2008. https://doi.org/10.1590/S1413-70542008000200001

SANTOS, H. G.; JACOMINE, P. K. T.; ANJOS, L. H. C.; OLIVEIRA, V. A.; LUMBRERAS, J. F.; COELHO, M. R.; ALMEIDA, J. A.; CUNHA, T. J. F.; OLIVEIRA, J. B. Sistema Brasileiro de Classificação de Solos. 3 ed. Brasília, Embrapa, 2013. 353p.

SILVA, R. A.; SIQUEIRA, G. M.; COSTA, M. K. L.; GUEDES FILHO, O.; SILVA, E. F. F. Spatial variability of soil fauna under different land use and managements. Revista Brasileira de Ciência do Solo, v. 42, p. 1-18, 2018. https://doi.org/10.1590/18069657rbcs20170121

SINGH, J. S.; REGHBANSHI, A. S.; SINGH, R. S. Microbial biomass acts as a source of plant nutrients in dry tropical forest and savanna. Nature, v. 338, p. 499-500, 1989. https://doi.org/10.1038/338499a0

SMITH, P.; HOUSE, J. I.; BUSTAMANTE, M.; SOBOCKÁ, J.; HARPER, R.; PAN, G.; WEST, P. C.; CLARK, J. M.; ADHYA, T.; RUMPEL, C.; PAUSTIAN, K.; KUIKMAN, P.; COTRUFO, M. F.; ELLIOTT, J. A.; MCDOWELL, R.; GRIFFITHS, R. I.; ASAKAWA, S.; BONDEAU, A.; JAIN, A. K.; MEERSMANS, J.; PUGH, T. A. M. Global change pressures on soils from land use and management. Global Change Biology, v. 22, p. 1008-1028, 2016. https://doi.org/10.1111/gcb.13068

Soil Survey Staff. Keys to Soil Taxonomy. 12. ed. Washington: USDA - Natural Resources Conservation Service, 2014. 362p.

SOUSA, D. C.; MEDEIROS, J. C.; ROSA, J. D.; LACERDA, J. J. J.; MAFRA, A. L.; MENDES, W. S. Chemical attributes of agricultural soil after the cultivation of cover crops. Australian Journal of Crop Science, v. 11, p. 1497-1503, 2017. https://doi.org/10.21475/ajcs.17.11.11.pne799

SOUZA, D. M. G.; LOBATO, E. Cerrado: correção do solo e adubação. 2.ed. Brasília, Embrapa Informação Tecnológica, 2004. 416p.

TEDESCO, M. J.; GIANELLO, C.; BISSANI, C. A.; BOHNEN, H.; VOLKWEISS, S. J. Análise de solo, plantas e outros materiais. 2. ed. Porto Alegre: UFRGS, 1995. 174p. Boletim Técnico, 5.

VANCE, E. D.; BROOKES, P. C.; JENKINSON, D. S. An extraction method for measuring soil microbial biomass C. Soil Biology and Biochemistry, v. 19, p. 703- 707, 1987. https://doi.org/10.1016/00380717(87)90052-6

ZHANG, Q.; MIAO, F.; WANG, Z.; SHEN, Y.; WANG, G. Effects of long-term fertilization management practices on soil microbial biomass in China's cropland: a meta-analysis. Agronomy Journal, v. 109, p. $1183-$ 1195. 2017. https://doi.org/10.2134/agronj2016.09.0553 